\title{
Evaluation of two toxin binders effectivness in reducing zearalenone toxic effects on gilts
}

\author{
José Antonio Fierro ${ }^{1}$, Juan Carlos Medina', Luis Miguel Dong², Elizabeth Rodríguez²
}

\begin{abstract}
Zearalenone (ZEA), a mycotoxin recognized with estrogenic effects, has a contaminant prevalence in corn, sorghum and wheat, mainly being produced by fungi: Fusarium graminearum, and other species such as culmorum and tricintum. Zearalenone effects are estrogenic. Being swine one of the most sensitive animals. Gilts often present hyperestrogenism and manifest as vulvovaginitis and mammary glands enlargement. The objective of this study was to assess ZEA toxic effects in gilts, during 52 days' period, consuming naturally contaminated feed, using $1200 \mathrm{ppb}$ levels (ZEA) and verify two commercial toxin binders efficiency to reduce their potential detrimental effects. 24 recently weaned gilts were selected; first seven days were for adaptation, then each gilt was assigned within one of the four experimental groups identified as: 1) control diet without ZEA, 2) positive control diet with 1,200 ppb of ZEA, 3) challenge diet with $1,200 \mathrm{ppb}$ of ZEA and $1.5 \mathrm{~kg} / \mathrm{t}$ of organoaluminosilicate, 4) challenge diet with 1,200 ppb of ZEA and $1.5 \mathrm{~kg} / \mathrm{t}$ of aluminosilicate + yeast cell walls. The obtained information was analyzed through the statistical software SYSTAT, by the Tukey test where the difference of means was defined. The significance value was based on a $p<0.05$. There were statistically significant differences in reproductive tract weight and length, vulva volume and cervix width between treatments.
\end{abstract}

Keywords: Zearalenone, gilts, reproduction, organoaluminosilicate, vulvovaginitis, hyperestrogenism, toxin binders.

\section{Introduction}

Mycotoxins contamination is a problem with serious repercussions, both economic and health, human and animal. The United States Council on Science and Technology (CAST, 2003) reported that mycotoxins have caused annual economic losses of $\$ 932$ million dollars averaged, and reported $25 \%$ of crops worldwide to be contaminated with fungi capable to produce mycotoxins. Most of mycotoxins that are considered to be important are produced by three fungi genera (Aspergillus, Fusarium and Penicillium); also mention mycotoxins produced by the Claviceps fungi and those becoming increasingly important in human health that are mycotoxins produced by Stachybotrys fungi. Zearalenone (ZEA) is a mycotoxin reported with estrogenic effects, usually prevalent in corn, wheat and sorghum. The main producing fungi is Fusarium graminearum, although other species also produce it, such as culmorum and tricintum, optimal production conditions consist in low temperatures and high levels of humidity, considered as fall mycotoxin produced in the field, before harvest. The estrogenic effects of Zearalenone are manifested in the urogenital system, swine are considered to be the most sensitive animal species, particularly in weaning piglets, gilts and sows. Lesions are expressed as vulvovaginitis and enlargement of the mammary glands and reproductive tract. It has been reported that $1 \mathrm{ppm}$ is enough to produce in gilts hiperestrogenism (Kurtz and Mirocha 1978). Sever cases conduce in vaginal and rectal prolapse. (Cast, 2003).

Chemical methods that have been used to reduce mycotoxin contamination have no practical effect in the livestock industry.
Grain cleaning is recommended, however, partially reduce contamination. Aluminosilicates inclusion has not shown to be efficient in reducing ZEA problem, reason why, many different types of mixtures of aluminosilicates with organic compounds have been developed (high molecular weight polymers, enzymes, enzyme-producing microorganisms, cell wall polymers), however, available products in the market with such compound have shown different drawbacks against ZEA. (Research \& Marketing press 2020).

Therefore, another alternative is the development of partially substituted organoaluminosilicates, which are chemical compounds formed through reaction of specific aluminosilicates with organic compounds, adsorption capacity increase, due that is based on the ability to adsorb polar and less

-polar compounds, as the case with ZEA. An additional feature of these adsorbents is that they are harmless and can easily incorporated into finished foods. Mallmann et al., 2005; Fierro et al., 2005-2006, demonstrated the effectiveness of a commercial organoaluminosilicate (completely substituted) in gilts, intoxicated with $2,000 \mathrm{ppb}$ of ZEA. It is also mentioned that esterified glucomannan-based low inclusion level mycotoxin adsorbent products based with yeast cell walls (Saccharomyces cerevisiae) designed to adsorb a wide range of mycotoxins and act rapidly. Its use in all species is a powerful tool to limit the negative effects when consumption of ingredients naturally contaminated with mycotoxins that can affect animals. Therefore, it is necessary to evaluate them and demonstrate their proven effectiveness in ZEA control.

*NUTEK S.A. de C.V. - Email: carlos.medina@sanfer.com.mx.

**Sanfer Salud Animal S.A. 7 Norte 416. Tehuacán, Pue. 75700 México. 


\section{Objective}

Evaluate ZEA toxic effects in gilts and the efficiency of two toxin binders to reduce ZEA bioavailability during 52 days' trail period.

\section{Material and methods}

Twenty-four recently weaned sows were selected and placed in individual pens. First seven days were for adaptation. Subsequently, each animal was assigned within one of the four experimental diets, identified as: 1) control diet, without ZEA, 2) intoxication diet with ZEA, $1200 \mathrm{ppb}, 3)$ challenge diet with $1200 \mathrm{ppb}$ of ZEA plus 1.5 $\mathrm{kg}$ / organoaluminosilicate 4) challenge diet with $1200 \mathrm{ppb}$ of ZEA plus $1.5 \mathrm{~kg} /$ Commercial Patented Aluminosilicate + yeast cell walls product classified as CPA+Y (Alltech 2020).

At the beginning all gilts were weighed (28 days old) individual weight was recorded every week, until the end of the experiment. Because ZEA estrogenic effects manifests vulva inflammation and redness, and growth in reproductive organs, these parameters were considered to measure ZEA toxicity, feed conversion was calculated weekly, as well, vulva (length $x$ width $x$ depth). Environmental and all animal health conditions were recorded daily.

All sows were euthanized and the reproductive system was removed to measure its dimensions, length, width and weight, including the weights of the vulvas. The percentage of the weight of the reproductive tract in relation to the weight of the animal was calculated. Reproductive tract samples were obtained for histopathological tests $\mathrm{o}$ and if organs were observed with some damage, lesion were recorded.
The obtained information was analyzed through the statistical software SYSTAT, by the Tukey test where the difference of means was defined. The significance value was based on a $p$ $<0.05$.

\section{Results and Discussion}

Macroscopically, ZEA toxic effects were observed between treatments, vulva and the reproductive tract increased for some treatments, but not in the negative control group. There were statistically significant differences in the percentage of the weight of the reproductive tract, vulva and reproductive tract length; cervix width and vulva volume (table 2 and 3 ). Regarding the productive parameters such as weight gain, feed conversion and feed consumption (table 5), there were no statistically significant differences among treatments for uterus and uterine horns, only numerical (Table 4),

Histopathological analyzes showed ZEA effects in animals within positive treatments, and as expected in the control group, no effect was observed.

The efficiency of organoaluminosilicate product, calculated based on its capacity to reduce the increase of the relative weight of the reproductive tract, was $61.5 \%$. Otherwise, in the case of product composed of aluminosilicate plus yeast cell walls $(C P A+Y)$, the relative weight of the reproductive tract has a significant increase, which means that its efficiency was zero percent. The organoaluminosicate showed effectiveness, unlike yeast wallbased products, and has proven to be a secure option against ZEA prevalent in many food and feed ingredients.

Table 1: Experimental treatments

\begin{tabular}{c|c|c|c}
\hline Treatments & $\begin{array}{c}\text { Organoaluminosilicate } \\
(\mathrm{kg} / \mathrm{t})\end{array}$ & $\begin{array}{c}\mathrm{CPA}+\mathrm{Y} \\
(\mathrm{kg} / \mathrm{t})\end{array}$ & $\begin{array}{c}\text { Zearalenone } \\
(\mathrm{mg} / \mathrm{kg})\end{array}$ \\
\hline Negative Control & 0 & 0 & 0 \\
\hline Positive Control & 0 & 0 & 1,170 \\
\hline Organoaluminosilicate & 1.5 & 0 & 1,200 \\
\hline $\mathrm{CPA}+\mathrm{Y}$ & 0 & 1.5 & 1,150 \\
\hline
\end{tabular}

Table 2: Relative weights of the reproductive tract and vulva

\begin{tabular}{c|c|c}
\hline \multirow{2}{*}{ Treatments } & $\begin{array}{c}\text { Reproductive tract \% } \\
\text { weight in relation to } \\
\text { animal weight. }\end{array}$ & $\begin{array}{c}\text { Vulva \% weight in } \\
\text { relation to the weight } \\
\text { of the animal }\end{array}$ \\
\cline { 2 - 3 } Negative Control & Mean \pm S. E & Mean \pm S. E \\
\hline Positive Control & $1.12 \pm 0.172^{\mathrm{a}}$ & $0.241 \pm 0.028^{\mathrm{a}}$ \\
\hline Organoaluminosilicate & $2.34 \pm 0.196^{\mathrm{b}}$ & $0.465 \pm 0.047^{\mathrm{ab}}$ \\
\hline CPA+Y & $1.87 \pm 0.179^{\mathrm{ab}}$ & $0.401 \pm 0.006^{\mathrm{ab}}$ \\
\hline
\end{tabular}

Means with different letters are statistically significant for $p<0.05$ 
Table 3: Reproductive tract scores

\begin{tabular}{|c|c|c|c|}
\hline & $\begin{array}{l}\text { Reproductive } \\
\text { tract length } \\
(\mathrm{cm})\end{array}$ & $\begin{array}{l}\text { Vulva volume } \\
\left(1000^{*} \mathrm{~cm} 3 / \mathrm{kg}\right)\end{array}$ & $\begin{array}{l}\text { Cervix width } \\
(\mathrm{cm})\end{array}$ \\
\hline & Mean \pm S. E & Mean \pm S. E & Mean \pm S. E \\
\hline Negative Control & $22 \pm 1.40^{a}$ & $0.100 \pm 0.017^{a}$ & $1.8 \pm 0.216^{a}$ \\
\hline Positive Control & $28.1 \pm 1.13^{b}$ & $0.620 \pm 0.057^{b}$ & $2.9 \pm 0.150 b$ \\
\hline Organoaluminosilicate & $24.3 \pm 1.11 \mathrm{ab}$ & $0.563 \pm 0.074^{b}$ & $2.2 \pm 0.132 \mathrm{ab}$ \\
\hline $\mathrm{CPA}+\mathrm{Y}$ & $28.5 \pm 1.77^{b}$ & $0.864 \pm 0.189 \mathrm{~b}$ & $2.9 \pm 0.229 b$ \\
\hline
\end{tabular}

Table 4: Reproductive tract dimensions II

\begin{tabular}{c|c|c}
\hline \multirow{2}{*}{ Treatments } & $\begin{array}{c}\text { Uterus width } \\
(\mathrm{cm})\end{array}$ & $\begin{array}{c}\text { Uterine horns length } \\
(\mathrm{cm})\end{array}$ \\
\cline { 2 - 3 } & Mean $\pm \mathrm{S} . \mathrm{E}$ & $37.5 \pm 1.89^{\mathrm{a}}$ \\
\hline Negative Control & $1.5 \pm 0.202^{\mathrm{a}}$ & $50.0 \pm 6.42^{\mathrm{a}}$ \\
\hline Positive Control & $2.0 \pm 0.309^{\mathrm{a}}$ & $39.3 \pm 3.30^{\mathrm{a}}$ \\
\hline Organoaluminosilicate & $1.6 \pm 0.075^{\mathrm{a}}$ & $51.4 \pm 3.26^{\mathrm{a}}$ \\
\hline CPA+Y & $2.1 \pm 0.160^{\mathrm{a}}$ & $\mathrm{M}$ \\
\hline
\end{tabular}

Means with different letters are statistically significant for $p<0.05$

Table 5: Productive Parameters

\begin{tabular}{c|c|c|c}
\hline \multirow{2}{*}{ Treatments } & $\begin{array}{c}\text { Weight gain } \\
(\mathrm{kg})\end{array}$ & Feed conversion & $\begin{array}{c}\text { Feed intake } \\
(\mathrm{kg})\end{array}$ \\
\cline { 2 - 4 } & Mean $\pm \mathrm{S} . \mathrm{E}$ & Mean $\pm \mathrm{S} . \mathrm{E}$ & Mean $\pm \mathrm{S} . \mathrm{E}$ \\
\hline Negative Control & $30,466 \pm 1003^{\mathrm{a}}$ & $1.87 \pm 0.055^{\mathrm{a}}$ & $56,717 \pm 1319^{\mathrm{a}}$ \\
\hline Positive Control & $30,113 \pm 1192^{\mathrm{a}}$ & $1.89 \pm 0.059^{\mathrm{a}}$ & $56,508 \pm 1285^{\mathrm{a}}$ \\
\hline Organoaluminosilicate & $30,793 \pm 1186^{\mathrm{a}}$ & $1.81 \pm 0.036^{\mathrm{a}}$ & $55,492 \pm 1621^{\mathrm{a}}$ \\
\hline \multicolumn{2}{|c|}{$\mathrm{CPA}+\mathrm{Y}$} & $1.80 \pm 0.027^{\mathrm{a}}$ & $56,458 \pm 1409^{\mathrm{a}}$ \\
\hline
\end{tabular}

Means with different letters are statistically significant for $p<0.05$

\section{Bibliography}

Alltech. Mycotoxin Management (knowmycotoxins.com). 2020. Patented formula. Ingredient description as cited Https://www2. knowmycotoxyns.com/es/mycosobr.

CAST (Council for Agricultural Science and Technology). 2003. Mycotoxins: Risk in Plant, Animal, and Human Systems. Task Force Report No. 139. Ames, lowa, USA.

Europe Mycotoxin Detoxifiers Market - Growth, Trends, and Forecast (2020 - 2025). Research \& Marketing press 2020.

Fierro, J. A., Medina, J. C. 2005. Parámetros productivos y morfología de genitales en cerdas pre- púberes intoxicadas con 1,000 ppb de zearalenona. XL Congreso de la asociación mexicana de veterinarios especialistas en cerdos, AMVEC. León, Guanajuato.
Fierro, J. A., Medina, J. C., Pérez, R., Duran, L. y Rodríguez, E. 2006. Reducción de los efectos de las Aflatoxinas, zearalenona, Ocratoxina A y tricotecenos con la incorporación de adsorbentes de micotoxinas en alimentos balanceados: alcances y limitaciones. Memorias del $\mathrm{V}$ congreso latinoamericano de micotoxicología. Florianópolis. SC. Brasil.

Hagler, W. M. Jr., N. R. Towers, C. J. Mirocha, R. M. Eppley, and W. L. Bryden. 2001. Zearalenone: Mycotoxin or mycoestrogen?. Fusarium: Paul E. Nelson Memorial Symposium. APS Press, St. Paul, Minnesota. Pp. 321-331.

Kurtz, H. J. and C. J. Mirocha. 1978. Zearalenone (F2) induced estrogenic syndrome in swine. Pp 1256-1264. In T. D. Wyllie and L. G. Morehouse (Eds.) Mycotoxic Fungi, Mycotoxins, Mycotoxicoses. Vol. 2. Marcel Dekker, Inc., New York.

Mallmann, C. A., Lovatto, P. A., Dilkin, P., Almeida, C. A., Giacomini, L. e Rauber, R. H. 2005. Avaliaçăo de adsorvente zeotek frente a intoxicaçăo por zearalenona em suínos. Universidad Federal de Santa Maria, Rio Grande Do Sul, Brasil. 